\title{
Options for Greenhouse Gas Mitigation Strategies for Road Transportation in Oman
}

\author{
Patrick Amoatey, Hameed Sulaiman* \\ Department of Biology, College of Science, Sultan Qaboos University, Muscat, Sultanate of Oman \\ Email: ^hameed@squ.edu.om
}

How to cite this paper: Amoatey, P. and Sulaiman, H. (2017) Options for Greenhouse Gas Mitigation Strategies for Road Transportation in Oman. American Journal of Climate Change, 6, 217-229. https://doi.org/10.4236/ajcc.2017.62011

Received: June 15, 2016

Accepted: April 16, 2017

Published: April 19, 2017

Copyright @ 2017 by authors and Scientific Research Publishing Inc. This work is licensed under the Creative Commons Attribution International License (CC BY 4.0).

http://creativecommons.org/licenses/by/4.0/ (c) (i) Open Access

\begin{abstract}
Oman is a fast developing country where about $76 \%$ of registered vehicles as of 2014 were private cars with approximately one private car per household. The growth of automobile is faster than the growth of human population. From 2000-2009, Omani population has increased by $2 \%$ per annum while automobile usage in the country has increased by $4.3 \%$. The leadership of Sultanate of Oman has pledged to cut down greenhouse (GHG) emissions by $2 \%$ as a commitment to United Nation Framework Convention on Climate Change (UNFCCC). Due to very limited public transportation system, traffic congestion and emission from vehicles are high during working days since majority of individuals uses private vehicles as only means of transport. This paper seeks to combine mitigation measures adopted in selected Middle East and North Africa (MENA) and UNFCCC to suggest cost-effective measures suitable in reducing GHG emissions from road transportation sector in Oman. These measures will specifically reduce vehicular emissions during working days where car occupancy rates are very low in an economically sustainable way.
\end{abstract}

\section{Keywords}

Greenhouse Gas, Road Transport, Private Vehicles, Mitigation, Oman

\section{Introduction}

Urban environment is rapidly dominating the world. The current global urban population is about $50 \%$ in early 21 st century and it is expected to reach $60 \%$ by the year 2060 mostly in developing countries. Carbon dioxides $\left(\mathrm{CO}_{2}\right)$ is the major greenhouse gas ( $\mathrm{GHG}$ ) produced by vehicles in the urban areas as well as other gases such volatile organic compounds (VOCs), carbon monoxide (CO), oxides of nitrogen $\left(\mathrm{NO}_{\mathrm{x}}\right)$ which pose health threat to human population [1]. The amount and type of gaseous emissions produced by vehicles depend on the 
quantity of fossil fuel consumed, vehicle technology, fuel quality and land-use planning [2].

Oil is the dominant source of fuel for major modes of transportation of which road transportation alone accounts for $81 \%$ of total energy consumed [3]. Transport is responsible for $24 \%$ of total global GHG emissions with road transport contributing to $75 \% \mathrm{CO}_{2}$ emissions [4]. Current scientific and political consensus, as represented by the Intergovernmental Panel on Climate Change (IPCC), is that man-made emission of $\mathrm{CO}_{2}$ and other GHGs are causing a significant rise in global average temperature; over and above that might be due to any natural phenomena [5].

Oman is fast developing in the region where about $76 \%$ of registered vehicles as of 2014 were private cars with approximately one private car per household [6]. Governments, policy makers and businesses are urgently required to mitigate global warming and to seek cost effective measures to reduce GHG emissions in response to fast growing interest and concern about climate change over the decade [7]. The overdependence on private vehicles for both passengers and freight transport can be attributed to high income level of the country, low population density and long distance between towns and cities settlements. Another factor that is contributing to high number of private cars is due to cheap fuel, excellent road networks and unfavorable high temperature [8]. Increase in urbanization and centralization of governments ministries, institutes and business in the urban centers in Oman is another driver for high dependence of private vehicles as about three quarters of Oman's population are currently living in urban centers [9]. Several developed and developing nations around the world have started adapting mitigation measures to reduce GHG emissions in road transport sector as an alternative approach of combating global climate change. First and foremost, this paper seeks to assess and evaluate GHG inventories relating to road transportation sector within Middle East and North African (MENA) countries and Sultanate of Oman; secondly, to explore and evaluate the current GHG emission mitigation measures adopted by some selected developing countries. Finally, to recommend medium-term and long-term mitigation measures appropriate reducing GHG emissions in road transport sector in Oman.

\section{Current Transportation System in Oman and MENA Region}

The transportation is an important sector as it supports businesses and commerce and facilitates movement of general goods and services and other social activities thereby contributing to sustainable development. Thus, a good transportation system should not only harmonize economic growth with land-use planning and promotion of public transport systems but also conserve resources in environmentally friendly manner [10]. For instance, Oman needs a sustainable transport policy to reduce the traffic volume and reduce other road related problems such as accident and congestion, but the prospect of introduction of efficient metro and inter-city bus services would require effective and efficient 
road transportation policies and great amount to resource to implement it [6].

Most MENA countries share similarities in transportation modes, this could be due to similarities in terms of climate, Gross Domestic Product (GDP) due to similar natural resources but some countries e.g. United Arab Emirates (UAE) and Egypt has had a tremendous improvement in their road sectors over the years. Table 1 shows a few policies promoting the use of active transportation modes in the MENA region. It has been noticed that national policies regarding the promotion of walking and cycling are nonexistent in Oman and several also in other MENA regions with exception of UAE [11]. Oman is a member of the Gulf Cooperation Council (GCC) countries with less exposure to different mode and services of public, except Muscat the capital city where few buses and taxis are available, the situation is even worse in other regions e.g. Kuwait which lacks public transport system for commuters [12]. Limited public transport system in Oman can be attributed to the fact that automobile is increasing in a faster rate than the growth of human population. From 2000 to 2009, Omani population has increased by $2 \%$ per annum while automobile fleet in the country has increased by $4.3 \%$ [6] with average estimation of about 260 vehicles per 1000 population [9]. Figure 1 indicates a sharp increase in private vehicles registration of about $76 \%$ against other types of vehicles in 2014 . This rise could be due to improve standard of living and heavily subsidize importation tax and fuel by the government.

Table 1. Promotion of alternative transport in MENA regions.

\begin{tabular}{ccc}
\hline & \multicolumn{2}{c}{ National Policies to Promote } \\
\cline { 2 - 3 } Countries & Walking or Cycling & Public Transportation \\
\hline Bahrain & No & No \\
Egypt & No & Yes \\
Israel & No & Yes \\
Jordan & No & Yes \\
Kuwait & No & No \\
Libya & No & No \\
Morocco & No & Yes \\
Oman & No & No \\
Qatar & No & Yes \\
Saudi Arabia & No & Yes \\
Syria & No & Yes \\
Tunisia & No & Yes \\
Turkey & No & Yes \\
UAE & Yes & Yes \\
Yemen & No & No \\
\hline
\end{tabular}

Source: [13]. 


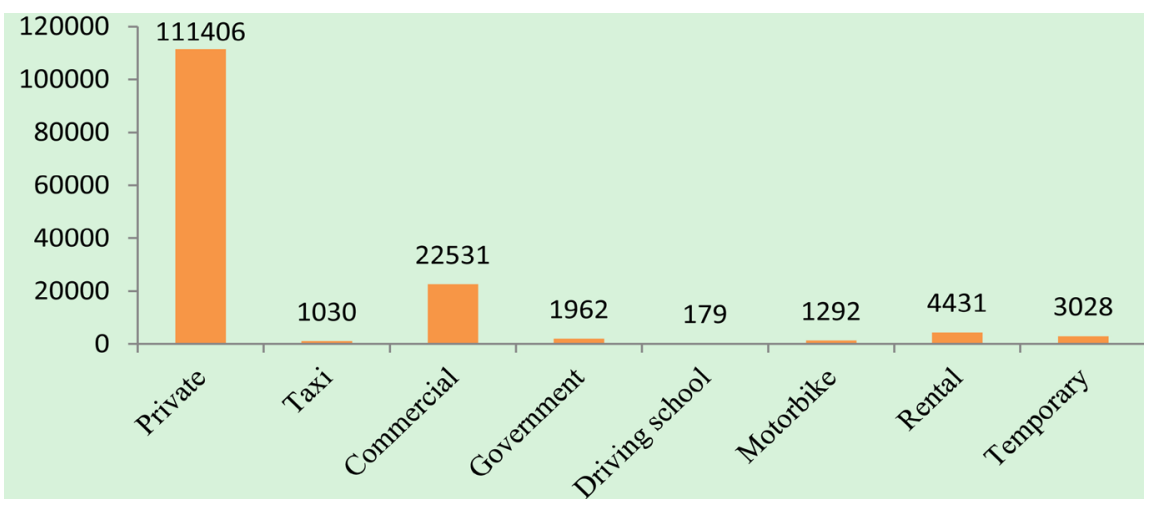

Figure 1. Distribution of registered vehicles by types in Oman in 2014 [14].

\section{3. $\mathrm{CO}_{2}$ Emissions in Oman and MENA Regions from Transportation}

The transportation sector alone in Arab region (including GCC countries) constituted about $22 \%$ of total GHG emissions of which $85 \%$ was attributed to urban transportation. In 2005, the total gasoline and diesel oil consumption in road transportation alone excluding low income countries like Comoros, Djibouti, Mauritania, Somalia and western Sahara, reached about 84 million tonnes of oil equivalents, and $\mathrm{CO}_{2}$ emissions reaching about 258.4 million tonnes [15]. Saudi Arabia represent $31 \%$ of fuel consumption in road transport, Morocco only $1 \%$, Palestine $0 \%$, Qatar $2 \%$ and Oman $2 \%$ which equivalent to about 5.2 million tonnes of $\mathrm{CO}_{2}$ emissions in only road as shown in Figure 2.

Table 2 presents $\mathrm{CO}_{2}$ emissions levels by sectors in MENA region in 2005. Transport sector, including road, rail, air, water, freight contributes to about $22 \%$ of $\mathrm{CO}_{2}$ in the region while Oman contributes to $13 \% \mathrm{CO}_{2}$ in transport sector with road being the major mode of transportation. A study assessed GHG inventories for energy sector in Oman using IPCC reference approach to analyze Oman's fuel supply of crude oil, natural gas, and petroleum refine products and amount of $\mathrm{CO}_{2}$ emitted as due to fuel combustion [16]. However, there is no study on GHG inventories in the road transport sector in Oman with regards to type of fuel used, age of vehicles and mileage, therefore hindering accurate estimation of GHG emissions produced from the road sector.

The current major fuel used for road transportation sector in Oman is either petrol or diesel while compressed natural gas (CNG) and electrically operated technologies are still waiting their ground to be explored. Figure 3 shows sector wise contribution of $\mathrm{CO}_{2}$ emissions in Oman compiled from sources during 2009 , this depicts that power, mostly oil and gas sector including refineries contributed to $35 \%$ of GHG emissions followed by transport sector of $26 \%$ [17]. Within the transport category, road transportation accounts for about $89 \%$ of $\mathrm{CO}_{2}$ emissions whiles air transportation accounts for only $11 \%$.

\section{Suggested Mitigation Measures in Road Transport in Oman}

Mitigation of climate change is designed to provide authoritative, timely infor- 


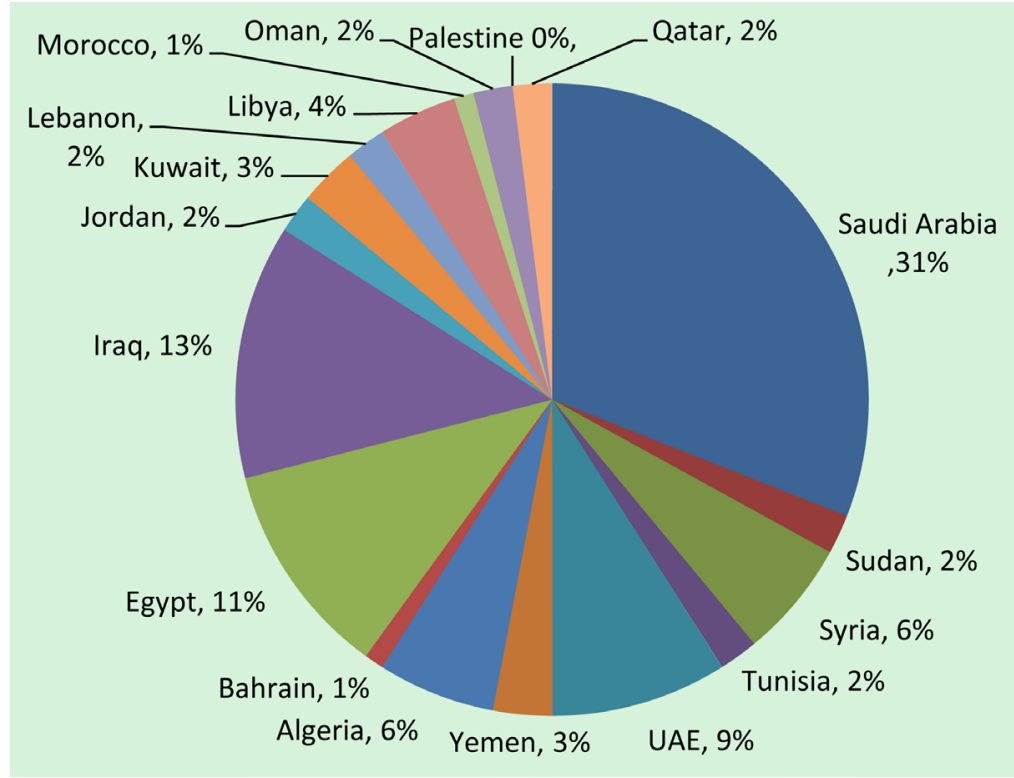

Figure 2. Distribution of fuel consumption in road transport in the Arab countries including Oman, 2009 [7].
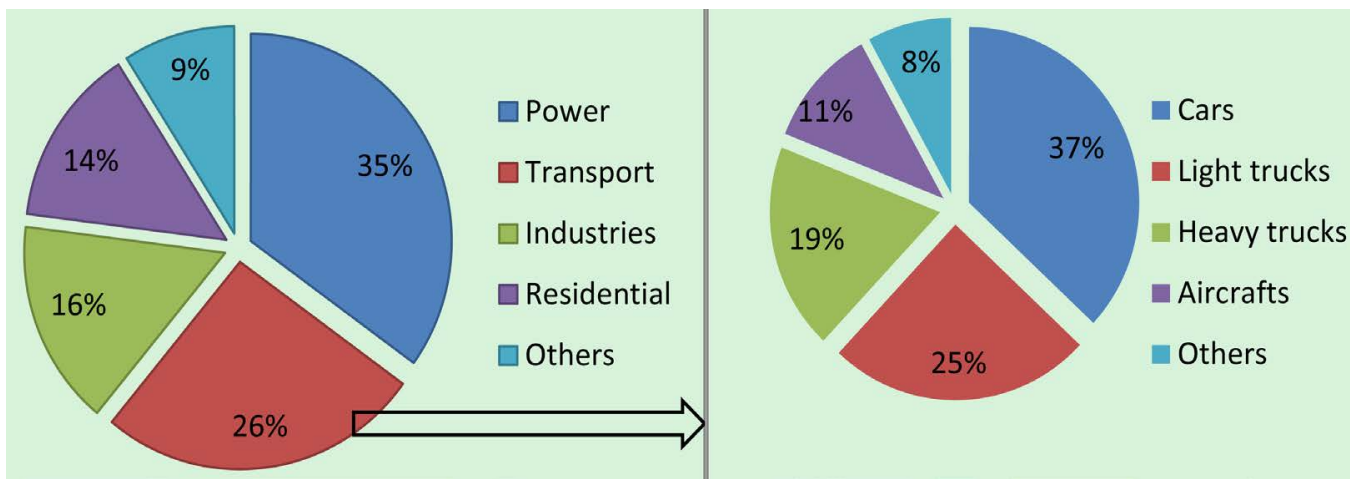

Figure 3. Sector wise $\mathrm{CO}_{2}$ emissions in Oman and categories of transport contribution during 2009 [17].

mation in all aspects of technologies and socio-economic policies, including cost effective measures to control GHG emissions. However, costly mitigation measures could have adverse effects on economic development. This dilemma facing policy makers results in tension that is manifested in the debate over the scale of the interventions and the balance to be adopted between climate policy and economic development [5]. Sultanate of Oman has experienced rapid urban expansion due to economic growth and economy booming after 1970 [16].

Currently, when public road transport services are attracting significant attention from policy makers globally as means of reducing GHG emissions, yet these services are low in Oman [12]. Table 3 shows measures adopted by some selected neighboring countries such as Kuwait, Egypt and Jordan (from MENA region) and UNFCC general mitigation measures in reducing GHG emissions in road transport sector. The rational for adapting mitigation measures from these countries was due to similarities in culture. Example, certain countries do not allow women to ride bicycles. Similarities in gross domestic product (GDP), and 
Table 2. $\mathrm{CO}_{2}$ emissions in Oman, GCC, MENA and global by sector in 2005 (extracted and modified from source).

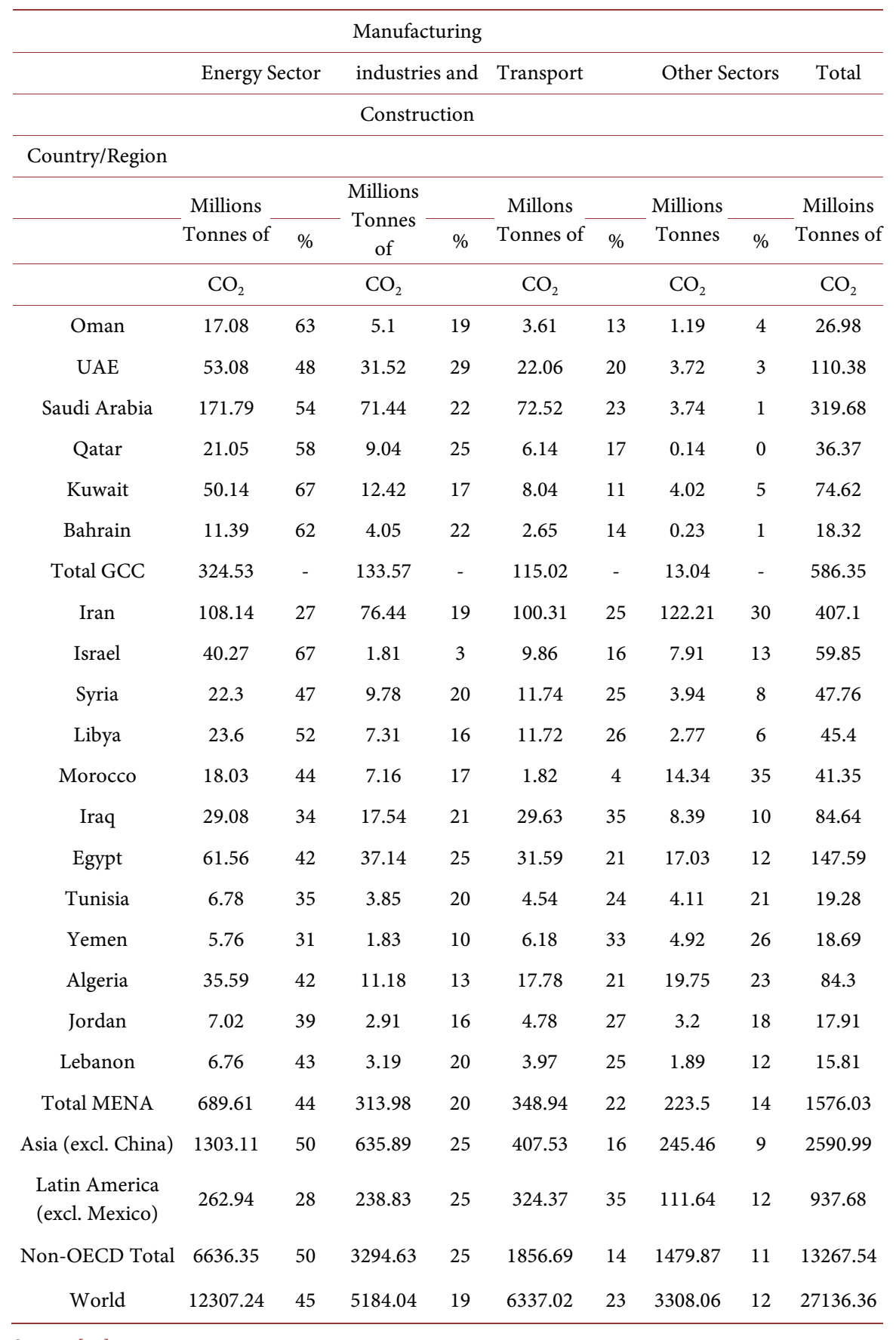

Source: [18].

per capita income in these countries and will make Sultanate of Oman some flexibility to implement these mitigation measures (Table 3). Institutional capacities and level of human capital stock are common among all these countries especially Kuwait, Jordan and Oman. Integrating these measures will help recommend the suitable short-term and long-term mitigation measures on how Sultanate of Oman can reduce GHG emissions based on their suitability, relevance and Oman's capacity for mitigation in the road sector (Response from a 
Table 3. Mitigation measures Adopted by some selected countries and UNFCCC on road transport sector.

\begin{tabular}{|c|c|c|c|c|c|}
\hline \multirow{2}{*}{$\begin{array}{l}\text { Country/ } \\
\text { Sector }\end{array}$} & \multirow{2}{*}{ Source } & \multicolumn{4}{|c|}{ Capacity to } \\
\hline & & & Yes & No & \\
\hline Kuwait & [19] & $\begin{array}{l}\text { - Improvement of fuel energy efficiency for light } \\
\text { vehicles } \\
\text { - Use of alternate fuels (compressed natural gas) } \\
\text { - Introduction of travel management demand } \\
\text { management system (smart growth land use } \\
\text { planning, advance management traffic system) }\end{array}$ & $\begin{array}{l}\sqrt{ } \\
\sqrt{ }\end{array}$ & & $\begin{array}{l}\text { Reduction in petrol and diesel demand } \\
\text { Reduction in } \mathrm{PM}_{10} \text { emissions } \\
\text { Will reduce traffic congestion and road } \\
\text { accidents }\end{array}$ \\
\hline Egypt & [20] & $\begin{array}{l}\text { - Improvement of vehicle maintenance and turning } \\
\text { of vehicle } \\
\text { - Use of compressed natural gas } \\
\text { - Re-introduction of electrified rail way in } \\
\text { inter-city and intra-city transport } \\
\text { - Intensifying the use of environmentally sound } \\
\text { river transport system } \\
\text { Extending metro line transport to newly } \\
\text { developed cities }\end{array}$ & $\begin{array}{l}\sqrt{ } \\
\sqrt{ }\end{array}$ & $\begin{array}{l}\sqrt{ } \\
\sqrt{ }\end{array}$ & $\begin{array}{l}\text { Reduction in } \mathrm{SO}_{2} \text { and } \mathrm{NO}_{\mathrm{x}} \text { emissions } \\
\text { Reduction in } \mathrm{SO}_{2} \text { and } \mathrm{NO}_{\mathrm{x}} \text { emissions } \\
\text { Will reduce fuel consumption and } \\
\text { decrease fuel congestion }\end{array}$ \\
\hline Jordan & [21] & $\begin{array}{l}\text { - Improve fuel energy efficiency of vehicles } \\
\text { - Tax and duty exemptions of newly imported taxis } \\
\text { - Introduction of double-deck buses in } \\
\text { municipalities. Improvement of traffic } \\
\text { management system } \\
\text { Tax exemptions on hybrid cars and incentives for } \\
\text { their use }\end{array}$ & $\sqrt{ }$ & $\begin{array}{l}\sqrt{ } \\
\sqrt{ } \\
\sqrt{ }\end{array}$ & $\begin{array}{l}\text { Will reduce emissions and long } \\
\text { distance journeys }\end{array}$ \\
\hline $\begin{array}{l}\text { United } \\
\text { Nation } \\
\text { Framework } \\
\text { Convention } \\
\text { on Climate } \\
\text { Change }\end{array}$ & [5] & $\begin{array}{l}\text { - } \quad \text { More fuel efficient vehicles } \\
\text { - } \quad \text { Hybrid vehicles } \\
\text { - } \text { Cleaner diesel vehicles and usage of biofuels } \\
\text { - } \quad \text { Model shift of road transport to railway } \\
\text { - } \quad \text { Public transport system } \\
\text { - } \quad \text { Land-use and transport planning } \\
\text { - } \quad \text { Tax on vehicle purchase and duty exemptions }\end{array}$ & $\begin{array}{l}\sqrt{ } \\
\sqrt{ } \\
\sqrt{ } \\
\sqrt{ } \\
\sqrt{ } \\
\sqrt{ } \\
\sqrt{ } \\
\sqrt{ }\end{array}$ & & $\begin{array}{l}\text { Reduction in } \mathrm{SO}_{2} \text { and } \mathrm{NO}_{\mathrm{x}} \text { emissions } \\
\text { Reduction in } \mathrm{PM}_{10} \text { emissions } \\
\text { Reductions in } \mathrm{SO}_{2} \text { and } \mathrm{NO}_{\mathrm{x}} \text { emissions } \\
\text { Will reduce road traffic accidents in } \\
\text { Oman } \\
\text { Reduction in number of private car } \\
\text { users } \\
\text { Reduction in money used in other } \\
\text { forms of transportation } \\
\text { Lowers traffic congestions and road } \\
\text { accidents } \\
\text { Will increase taxi users, increasing } \\
\text { vehicle occupancy rates }\end{array}$ \\
\hline
\end{tabular}

focused group discussion carried out for this review).

\subsection{Short-Term Mitigation Approach}

1) Non-motorized transport, NMT (Walking and cycling): Walking is the most basic urban transport mode for all short-to-medium length travel, cycling also plays a fundamental role in urban transport, especially in low and middle income countries throughout the MENA region. NMT in Cairo, Egypt was estimated to be $32 \%$ of all trips in 2001 [11]. Current survey shows that $52 \%$ NMT transport modes in Shebin El-Kom and 31\% in Faiyum, Egypt and field visits in different cities has higher share in walking and cycling, especially in middle size and smaller cities. The reason behind this high share can be estimated to the rel- 
atively short distances travelled to schools, universities and factories as well as cost associated to owning vehicles [22].

In the Netherlands, with strong policies and cultural commitment, the modal share of trains from home is about $35 \%$ to $40 \%$ [23]. In the UK where over $60 \%$ of people live within a 15 minute bicycle ride of a station, NMT has been increased UK due to convenient, secure bicycle parking stations [24]. However, walking and cycling depends on local weather condition [25]. This is totally different in Oman, the walking and cycling is possible in winter month which spans a quarter of the year. For the rest of the year, it is almost hostile to use this option. A target of one quarter of all trips in the major cities in Australia to be undertaken by walking and cycling, compared to the current average share of around $16 \%$, would contribute about $4.4 \mathrm{Mt}$ of the targeted $36 \mathrm{Mt}$ emissions reduction at 2020 [26].

2) Reliable public transport (Metro buses, transit buses): Public transport such as buses are significant from a socially sustainable point of view because it gives higher mobility to people who do not have access to car and also attractive from an economically sustainable perspective [5]. In Jordan, the government is considering the introduction of double-deck buses in Greater Amman and other municipalities to reduce fuel consumption and reduce GHG emissions [20], Abu Dhabi has enriched its public transport infrastructure with taxis and buses and it is offering free services to four major routes, However, the accessibility of public transport depends on perceptions and attitudes of citizens [12]. While buses are not a clean mode of transport, but once bus occupancy exceeds three people, the $\mathrm{CO}_{2}$ emissions per passenger kilometer are far lower than cars [3].

Currently the Government of Oman has increased the number of buses in major cities in the country as of mid 2016. Muscat governorate is currently operating about 36 buses with 28 buses on inter-city routes in addition to already existing 400 school buses serving various schools in the country. The Government of Oman is planning to increase this number in order to enhance reduction in traffic congestion, road accidents and $\mathrm{CO}_{2}$ emissions. Though, the patronage of the buses are gradually increasing, the current waiting times for the buses is about 15 - 20 minutes in afternoon and 15 - 30 minutes in the morning and evening when traffic congestion is at the peak level. These waiting times is expected to reduce in future as patronage and number of buses increases and while reducing traffic congestions [27].

3) Eco-driving: This can be explained as changes in driving practices that reduces fuel consumption and reduces emission of pollutants such as $\mathrm{CO}_{2}, \mathrm{SO}_{2}$, $\mathrm{NO}_{\mathrm{X}}, \mathrm{CO}$ in vehicles. Fuel-efficient driving practices, smoother acceleration and deceleration, keeping of engine revolution low, shutting off engine when idling, reducing maximum speeds and maintaining proper tire pressure [5] are ecodriving practices.

This option has the potential for both substantial immediate and long term benefits. Slower speed has the potential to provide extensive savings with some $15 \%-20 \%$ reduction in $\mathrm{CO}_{2}$ emissions if a maximum speed of limit $80 \mathrm{~km} / \mathrm{h}$ is 
introduced on motorways and truck roads. With lower speeds on other roads such as residential roads, effective compliance is likely to impact $\mathrm{CO}_{2}$ reduction [28]. This is lacking in Oman, according to a study conducted in 2012 [6] on causes of road accidents from 2000-2009 shows that 50\% of the traffic road accidents was due to high speeding, negligence or careless driving accounts for $29 \%$ while $3 \%$ is due to overtaking. Incorporating eco-driving skills and practices in driving schools and as a requirement for issuing driving licenses will help inculcates eco-driving skills that will contribute to GHG emissions.

4) Increasing urban car occupancy rate: According to European Environment Agency [29], vehicle occupancy rates can be used to explain changes in levels of vehicles ownership and to illustrate changes in the efficiency of mass passenger transport. Efficient usage of passenger vehicles results in the need for less vehicle-kilometer to transport the same number of passengers. Utilization efficiency is one of the main parameters that determine energy and emissions efficiency.

Increasing occupancy rates are the real opportunity to cut emissions provided this is achieved by lowering the number of cars on the road. This is a major focus of policy attention, with appropriate incentives. Government, institution, private companies, families and social groups should promote campaign among themselves and the general public on car shares as means of raising awareness of GHG reduction while reducing congestions and travel cost [26].

5) Taxation and pricing of fuel: Fuel tax encourages consumers to buy more energy efficient vehicles, tend to leads to fewer vehicles being bought, less traffic and more energy efficient driving behavior. Unlike the users of gasoline cars, the users of diesel cars and trucks may not pay the full social cost through fuel tax and other users [30].

This option does not seem to have political support at this time but has an advantage of promoting fuel conservation in many directions, particularly reduced driving and changes in driving behavior including speed in all vehicles [31]. In Oman, in the 2016 oil subsidies were removed by the Government due to the heavy fall in global oil prices, though the tax placed on the fuel was not so adequate to effect significant changes in fuel consumption and rise in decrease in private cars usage. This will still have some reduction GHG emissions as people may be conscious about the rise in fuel cost.

\subsection{Long-Term Mitigation Approach}

1) Railway (electric and hybrid trains): For long distance journeys and trades, rail is the only viable alternative. Wheels on rails are seen as ecologically aware form of transportation, being four times more efficient than road transportation for passengers and twice as efficient as freight [3]. In Europe and Japan, electricity is a major energy source for rail while diesel is a major source in North America [5]. In Dubai, construction of the US $\$ 7.6$ billion Metro system started in 2006 and piecemeal operation begun in 2009, once construction is completed, it will feature 87 driverless trains running on two lines comprising more than 75 kilometers of track [11]. Sultanate of Oman has long term objectives in develop- 
ing railway networks within the remote towns to ensure efficient transport of goods and services in future.

2) Alternate fuel (Biofuels): There are many alternative fuels on the market, many of which have lower carbon content than petrol and diesel, and including biofuels (methanol, ethanol, biodiesel). Ethanol and biodiesel are potentially most suitable to use in India. The government of India has already introduced a program of 5\% ethanol in petrol [28]. In Brazil, ethanol is used either in its pure replacing gasoline or as a blend with gasoline at a concentration of $20 \%-25 \%$. It is estimated that with $10 \%$ ethanol-gasoline blending and $20 \%$ biodiesel-diesel blending in Southern Africa, a reduction of $2.5 \mathrm{Mt}$ of $\mathrm{CO}_{2}$ and $9.4 \mathrm{Mt}$ of $\mathrm{CO}_{2}$ respectively can be realized annually [5]. Usage of biofuels may not economically feasible in Oman due to lack of arable lands for cultivation of crops for biofuel production as well as the already existing abundant and low cost fossil fuels.

3) Use of electric and hybrid cars and incentives for their usage: Hybrid vehicles provide an intermittent step between the internal combustion engine and electric motor. Energy management is used to optimize the fuel economy of both engines because electric and combustion engines work better under different driving situations [3].

Hybrid vehicles are currently in mass production with estimated 2006 global sales of 373,000, mainly in Japan and the US, compared with conventional petrol-engine cars, full hybrid can improve fuel efficiency by up to $60 \%$, with higher gains in urban driving [32]. This option can be tried in urban cities of Oman for short journeys which can help to reduce the number of big individual cars in the road. Electric vehicles are driven by electric motors with high efficiency more than $90 \%$. Although, the potential of $\mathrm{CO}_{2}$ reduction strongly depends on the power mix, $\mathrm{CO}_{2}$ emissions can be reduced by more than $50 \%$ compared to conventional gasoline [5].

4) Improvement of traffic management system: Urbanization and urban development are critical factors for $\mathrm{CO}_{2}$ emissions and mitigation; better urban designs have potential to influence energy consumptions and GHG emissions reduction [33]. Muscat, the capital city of Oman has well planned and sophisticated road infrastructure which helps the authorities to have a better traffic management system. However, due to the rebound effect, where efficiency gains are cancelled out by resulting increase in consumption. The ever increasing number of private cars may mask the overall expected benefits of traffic planning and management. In such cities, infrastructure development focused on provision for cars and trucks could accelerate the growth in use of these modes and decline in the use of less energy intensive-modes. Provision of non-motorized modes in new infrastructure is an important enabling factor for policies to encourage the use of these modes and to discourage individual car use [30].

\section{Conclusion}

This review investigates the current road transportation sector in Oman and MENA countries as a whole and how it influences GHG emissions and the sug- 
gested plausible mitigation measures. Achieving reductions in road transport GHG emissions requires a much broader policy response [26]. Although certain policies can respond quickly to the pressure, in reality it is a slow process and there is a growing expectation on how new technologies can deliver the solution [3]. Introduction of satellite navigation technology in road transport sector in Oman can provide accurate data on annual mileage of vehicles according to vehicle type, type of fuel, age of the car, purpose of the trip and car occupancy. This will help in planning, management and implementation of appropriate policies to mitigate GHG emissions from road transportation sector. It may be impossible to respond to the challenges of transport sector GHG emission mitigation by the government alone without much support from changes in the conveyance lifestyle from the general public [30]. Public education and awareness from opinion leaders, private and non-governmental organizations on the impact of road transport on the environment can also contribute to GHG reductions from road transport sector in Oman.

\section{References}

[1] Baeza, C. and Sheinbaum-Pardo, C. (2014) Sustainable Passenger Road Transport Scenarios to Reduce Fuel Consumption, Air Pollutants and GHG (Greenhouse Gas) Emissions in the Mexico City Metropolitan Area. Energy, 66, 624-634.

[2] Thambiran, T. and Diab, R.D. (2011) Air Pollution and Climate Change Co-Benefit Opportunities in the Road Transportation Sector in Durban, South Africa. Atmospheric Environment, 45, 2683-2689.

[3] Chapman, L. (2007) Transport and Climate Change: A Review. Journal of Transport Geography, 15, 354-367.

[4] International Energy Agency (IEA) (2009) Transport, Energy and $\mathrm{CO}_{2}$ : Moving towards Sustainability. International Energy Agency (IEA), Paris.

[5] Intergovernmental Panel on Climate Change (IPCC) (2007) Mitigation of Climate Change, Fourth Assessment Report. Intergovernmental Panel on Climate Change, Geneva.

[6] Islam, M.M. and Al Hadhrami, A.Y. (2012) Increased Motorization and Road Traffic Accidents in Oman. Journal of Emerging Trends in Economics and Management Sciences, 3, 907.

[7] Yousef, A., Eliskandarani, E. and Elsarrag, E. (2014) Approaches to Reducing Carbon Dioxide Emissions in the Built Environment: Low Carbon Cities. International Journal of Sustainable Built Environment, 3, 167-178.

[8] Sookun, A., Boojhawon, R. and Rughooputh, S.D.D.V. (2014) Assessing Greenhouse Gas and Related Air Pollutant Emissions from Road Traffic Counts: A Case Study for Mauritius. Transportation Research Part D: Transport and Environment, 32, 35-47.

[9] Nakat, E. and Salim, Z. (2015) Institutional and Governance Structure of Oman's Transport Sector: Challenges and Options for Reforms. World Bank, Washington. DC.

[10] Yung, H.S.C., Chang, Y. and Lu, I. (2015) Urban Transportation Energy and Carbon Dioxide Emission Strategies. Applied Energy, 157, 953-973. https://doi.org/10.1016/j.apenergy.2015.01.126

[11] El-Geneidy, A., Diab, E., Jacques, C. and Mathez, A. (2013) Sustainable Urban Mo- 
bility in the Middle East and North Africa. Global Report on Human Settlements.

[12] Belwal, R. and Belwal, S. (2010) Public Transportation Services in Oman: A Study of Public Perceptions. Journal of Public Transportation, 13, 1. https://doi.org/10.5038/2375-0901.13.4.1

[13] World Health Organization (2009) Global Status Report on Road Safety: Time for Action. World Health Organization, Geneva.

[14] National Centre for Science Information (2015) Statistical Year Book. National Centre for Statistics and Information, Muscat.

[15] United Nations Economic and Social Commission for Western Asia (2009) Transport for Sustainable in the Arab Region: Measures, Progress Achieved and Policy Framework. Economic and Social Commission for Western Asia.

[16] Abdul-Wahab, S.A., Charabi, Y., Al-Maamari, R., Al-Rawas, G.A., Gastli, A. and Chan, K. (2015) $\mathrm{CO}_{2}$ Greenhouse Emissions in Oman over the Last Forty-Two Years: Review. Renewable \& Sustainable Energy Reviews, 52, 1702-1712. https://doi.org/10.1016/j.rser.2015.07.193

[17] Solanki, P.S., et al. (2013) Estimation and Diminution of CO2 Emissions by Clean Development Mechanism Option at Power Sector in Oman. International Journal of Energy and Environment, 4, 641-652.

[18] Zhang, Y. (2008) Opportunities for Mitigating the Environmental Impact of Energy Use in the Middle East and North Africa Region. Energy Sector Management Assistance Program. World Bank, Washington DC.

[19] UNFCCC (2012) Kuwait's Initial National Communication. The United Nations Framework Convention on Climate Change, Bern.

[20] Gelil, I.A. (2008) GHG Emissions: Mitigation Efforts in the Arab Countries.

[21] UNFCCC (1997) Jordan's Initial National Communication. The United Nations Framework Convention on Climate Change, Bern.

[22] Al-Bassam, E., Khan, A. and Popov, V. (2009) Management of Air Quality in the Vicinity of Congested Area of Kuwait. Environmental Monitoring and Assessment, 157, 539-555.

[23] Riettveld, P. (2001) The Position of Non-Motorized Transport Modes in Transport Systems. Hand Book of Transport Systems and Traffic Control.

[24] ECMT (2004) Transport and Spatial Policies: The Role of Regulatory and Fiscal incentive. Organization for Economic Cooperation and Development (OECD), Paris.

[25] ECMT (2004) National Policies to Promote Cycling. Organization for Economic Cooperation and Development (OECD), Paris.

[26] Stanley, J.K., Hensher, D.A. and Loader, C. (2011) Road Transport and Climate Change: Stepping off the Greenhouse Gas. Transportation Research Part A: Policy and Practice, 45, 1020-1030. https://doi.org/10.1016/j.tra.2009.04.005

[27] Times of Oman (2016) Times of Oman : Oman Transport: Mwasalat Expands Network, More Buses to Sohar, Nizwa.

http://timesofoman.com/article/84799/Oman/Transport/Oman-transport:-Mwasala t-expands-network-more-buses-to-Sohar-Nizwa.

[28] Hickman, R., Ashiru, O. and Banister, D. (2011) Transitions to Low Carbon Transport Futures: Strategic Conversations from London and Delhi. Journal of Transport Geography, 19, 1553-1562. https://doi.org/10.1016/j.jtrangeo.2011.03.013

[29] EEA (2010) Occupancy Rate of Passenger Vehicles. European Environment Agency, Denmark.

[30] Davidson, O. and Michaelis, L. (1996) GHG Mitigation in the Transport Sector. 
Energy Policy, 24, 969-984. https://doi.org/10.1016/S0301-4215(96)80361-2

[31] Small, K.A. (2012) Energy Policies for Passenger Motor Vehicles. Transportation Research Part A: Policy and Practice, 46, 874-889.

https://doi.org/10.1016/j.tra.2012.02.017

[32] Moriarty, P. and Honnery, D. (2008) The Prospects for Global Green Car Mobility. Journal of Cleaner Production, 16, 1717-1726.

https://doi.org/10.1016/j.jclepro.2007.10.025

[33] Makido, Y., Dhakal, S. and Yamagata, Y. (2012) Relationship between Urban form and $\mathrm{CO}_{2}$ Emissions: Evidence from Fifty Japanese Cities. Urban Climb, 2, 55-67. https://doi.org/10.1016/j.uclim.2012.10.006

Submit or recommend next manuscript to SCIRP and we will provide best service for you:

Accepting pre-submission inquiries through Email, Facebook, LinkedIn, Twitter, etc. A wide selection of journals (inclusive of 9 subjects, more than 200 journals) Providing 24-hour high-quality service User-friendly online submission system Fair and swift peer-review system Efficient typesetting and proofreading procedure Display of the result of downloads and visits, as well as the number of cited articles Maximum dissemination of your research work

Submit your manuscript at: http://papersubmission.scirp.org/

Or contact ajcc@scirp.org 